\title{
Socioeconomic Indicator of Water Availability in the Lower Guayalejo-Tamesí River Basin
}

\author{
Lidia Rangel-Blanco \\ Faculty of Law and Social Sciences, Autonomous University of Tamaulipas, Ciudad Victoria, México \\ Email: lrange@docentes.uat.edu.mx
}

How to cite this paper: Rangel-Blanco, L. (2017) Socioeconomic Indicator of Water Availability in the Lower Guayalejo-Tamesí River Basin. Journal of Geoscience and Environment Protection, 5, 47-62. https://doi.org/10.4236/gep.2017.56007

Received: April 21, 2017

Accepted: June 11, 2017

Published: June 14, 2017

Copyright $\odot 2017$ by author and Scientific Research Publishing Inc. This work is licensed under the Creative Commons Attribution International License (CC BY 4.0).

http://creativecommons.org/licenses/by/4.0/

\section{cc) (i) Open Access}

\begin{abstract}
Water is the main element for development since it defines and limits the opportunities for growth and economic development. The lack of water will increase constantly owing to the increase of the economic activities, social requests, environmental damage, and the climate changes. The research has as purpose to build an indicator of water availability, in the lower Basin of Guayalejo-Tamesi River in Tamaulipas, Mexico. Considering a quantitative methodology that provides the application of mathematic models through a hydrologic simulation software and scenarios of climate change (WEAP) (MAGICC); and the qualitative that represents a major economic engineering challenge to convert complex variables such as the human development, the rise of the economic activity, and the increase of the social-demographic in water requirement. Bearing in mind that the valley is one of the most important hydrological systems of the State of Tamaulipas that provides to productive areas; the chemical industry, petrochemical, energetic, agricultural and livestock such as the domestic. Which makes relevant to apply and analyze the IDA, being a new experience at the regional level that needs to be abroad in a general way by the binding instances to the development of these areas which will allow a better social usage and economic of the hydrological system in a sustainable integral environment.
\end{abstract}

\section{Keywords}

Water Availability, Binding Indicator, Sustainability

\section{Introduction}

The indicators are standards that allow, through concrete data, the monitoring and the transfer of information about the behavior of the reality and its evolution and trending. According to [1], nowadays in the world there has been working to develop methodologies of Indicators of Sustainable Development (ISD) of the third generation; indicators of first generation are the ones which 
usually receive the name of environmental indicators or environmental sustainability, which happened between the 80s and currently (depending on the initiative), where there has been designed and implemented indicators of partial sustainability that realize about complex phenomena from a productive sector (health, agricultural, forest) or well, from the singularity or by a reduced number of dimensions (environmental referred to pollution variable or of natural resources).

On other hand, the second generation of indicators corresponds to the development accomplished from the multidimensional approach of the sustainable development. This is a considerable step forward in the design and implementation of ISD systems compound by indicators of social, economic and institutional type, however, beyond achieving a solid work in terms of each indicator proposed was a synthesis of the four dimensions of sustainable development or, at least, it will embed more than one dimension, what has been achieved is to introduce indicators jointly from the four dimensions, without actually extending in an essential way and tend to preserve individually their sectoral disciplinary profile.

Designing and implementing third-generation IDS is a major challenge that transcends the two generations previously enunciated in the sense of producing binding indicators, which in low numbers allow us to have a quick access to a much larger world of meanings in which the economic, social and environmental are incorporated in a transversal and systematic way. It is no longer about of taking indicators from different areas and placing them together with the intention to be a system. Neither is it about adding them through indicators or looking for a common unit of measurement because these developments run into important methodological and axiological situations.

The purpose of this research is to build a water availability indicator within climate change scenarios, binding of environmental variables, social and economic. Having in mind the determination and characterization of the study of the area in its physic environment and socioeconomic, The analysis of scenarios of climate change at the regional level in the study area, considering the methodology elaborated by Instituto Nacional de Ecología [2] in relation to the variables precipitation and temperature; the analysis of the results of the modeling of water availability 2010-2013 for the lower basin of Guayalejo Tamesi, identifying areas of hydric stress and lastly adapting and applying a methodology in the area to stablish relationships between the geostatistical information and socioeconomic aspects of hydric services users to lead the ones that take decisions in the objective application of priority projects to application of a sustainable plan of valley manage in a short, medium and long term; covering the towns Altamira, Madero and Tampico, which correspond to the hydrological area RH 26 that comprises the lower basin of the River Guayalejo Tamesi from the State of Tamaulipas, Mexico.

\section{Characterization of the Study Zone}

The Guayalejo Tamesí river basin has a drained basin area of $17,084 \mathrm{~km}^{2}$ with a yearly registered average runoff of $2198 \mathrm{~m}^{3}$ in the Magiscatzin Station; heading 
the first place in its water exploitation due to the existence of important irrigation system. Most part of the basin is located in Tamaulipas adjoining towards the north with the basin of Soto la Marina River to the west with the Basin of Salado River and to the south with Panuco's River stream.

The yearly demographic average growth in the study area according to [3] [4] to the period 2005-2010 was estimated in 1.3\% showing the same growth in urban population like in rural. On other hand, the projected trend population until 2030 is represented by [5] in the Table 1 .

\section{Compilation of Information on Environmental, Social and Economic Variables for the Incorporation to IDA}

Since the identification of relevant variables of the information banks that are available and generated can be interpreted a series of criteria and indicators that, indirectly, allow to establish relationships, make links of information and reach conclusions to understand not only a regional geographic scenario on the current status of the basins, but also the uses that have led to their current situation.

Municipal and local information is obtained from economic, demographic and socioeconomic aspects that mainly influence or affect the hydric cycle in the basin. Finally, indicators that best reflected the basin data were selected.

\subsection{Environmental Variables}

The environmental variables which are important to analyze in this research are: historical, current and future temperature until 2030; historical, current and future precipitation changes until 2030, and the availability of water in the lower basin of Guayalejo-Tamesí River that corresponds to the State of Tamaulipas (Tampico, Madero and Altamira).

The application of the Atmosphere-Ocean Global Circulation Models (AOG$\mathrm{CM}$ ) to the study area, during the application of the project of Evaluation and Monitoring of the climate change vulnerability in Tamaulipas Coasts (EMOVUCOST, 2014) project, was made through the MAGICC/SCENGEN v5.3 program which is documented by Wigley, (2008). This 5.3 version of the MAGICC/SCENGEN program incorporates the stablished criteria in the Fourth Evaluation Report of the Work Team 1 from IPCC. The MAGICC module (Model for the Assessment of Greenhouse-gas Induced Climate Change) of this program is a

Table 1. Population trend 1 2005-2030.

\begin{tabular}{ccccccc}
\hline Municipality & 2005 & $\mathbf{2 0 1 0}$ & $\mathbf{2 0 1 5}$ & $\mathbf{2 0 2 0}$ & $\mathbf{2 0 2 5}$ & $\mathbf{2 0 3 0}$ \\
\hline Tampico & 307450 & 305906 & 301945 & 296711 & 290344 & 282601 \\
Madero & 194617 & 198605 & 200638 & 201426 & 201013 & 199194 \\
Altamira & 161346 & 192768 & 223136 & 252214 & 279601 & 304529 \\
Total & $\mathbf{6 6 3 4 1 3}$ & $\mathbf{6 9 7 2 7 9}$ & $\mathbf{7 2 5 7 1 9}$ & $\mathbf{7 5 0 3 5 1}$ & $\mathbf{7 7 0 9 5 8}$ & $\mathbf{7 8 6 3 2 4}$ \\
\hline
\end{tabular}

Source: National Population Council, 2010. 
climate model joined in an interactive form with different gas cycles that allow to stablish future atmospheric concentrations in the main green-house gases. The SCENGEN module (Global and Regional Climate Chanarnge Sceio Generator) uses global average temperature exits of MAGICC in order to generate space patterns of temperature, precipitation and atmospheric pressure changes from a data base of AOGCM models.

Nevertheless, due to the resolution of MAGICC/SCENGEN is of $2.5 \times 2.5$ variability grades, because of that it appeals to the application of scale reduction to consider the study in local impacts and in a particular way to have clearer data by town to consider the projection of scenarios of climate change corresponding to the study area.

In order to reach its objective, in the lower basin of the Guayalejo-Tamesí River, it was necessary to do an extra effort to obtain the regional scenarios for climate change by applying what is generically known as downscaling, which has lately gained a strong interest and is also one of the main objectives of the current climate changes projects from different governments, in order to carry out impact studies and appropriate arrangement plans. Obtaining the following temperature and precipitation results projected until 2030 in the south of the State of Tamaulipas (Tampico, Madero y Altamira).

\subsubsection{Precipitation}

For 2015 , in the south area, a decrease of the precipitation from $5 \%$ to $6.5 \%$ is observed according to the average base precipitation from the period 1971-2000, which changed from 766 to $1246 \mathrm{~mm}$ per year. This means that the projection of the precipitation can now change between 716.2 to $1165.0 \mathrm{~mm}$ per year.

For 2030 in the south area a decrease of the precipitation from $55 \%$ to $6.5 \%$ is observed according to the average base precipitation from the period 1971-2000 which changed from 766 to $1246 \mathrm{~mm}$ per year. This means that the projection of the precipitation can now change between 716.3 to $1165.0 \mathrm{~mm}$ per year.

\subsubsection{Temperature}

De For 2015, in the south area, an increase of the temperature from $0.44^{\circ} \mathrm{C}$ to $0.4^{\circ} \mathrm{C}$ is observed according to the average base temperature of the period $1971-2000$ which changed between $19.9^{\circ} \mathrm{C}$ and $22.5^{\circ} \mathrm{C}$ per year. This means that the projection of the temperature can change between $20.3^{\circ} \mathrm{C}$ and $23.0^{\circ} \mathrm{C}$ per year (Figure 1).

For 2030 , in the south area, an increase of the temperature from $0.86^{\circ} \mathrm{C}$ to $0.94^{\circ} \mathrm{C}$ is observed according to the average base temperature of the period 1971-2000 with a change between $20.4^{\circ} \mathrm{C}$ and $22.5^{\circ} \mathrm{C}$. This means that the projection of the temperature can change between $21.3^{\circ} \mathrm{C}$ and $23.4^{\circ} \mathrm{C}$ in the area which represents an average increase of $0.07^{\circ} \mathrm{C}$ per year until 2030 as it appears in the next images (Figure 2).

The data concerning to the basin of Guayalejo-Tamesi River were filtrated using the WEAP Program. The availability of precipitation and temperature records of the stations located in the lower basin of Guayalejo Tamesi River 


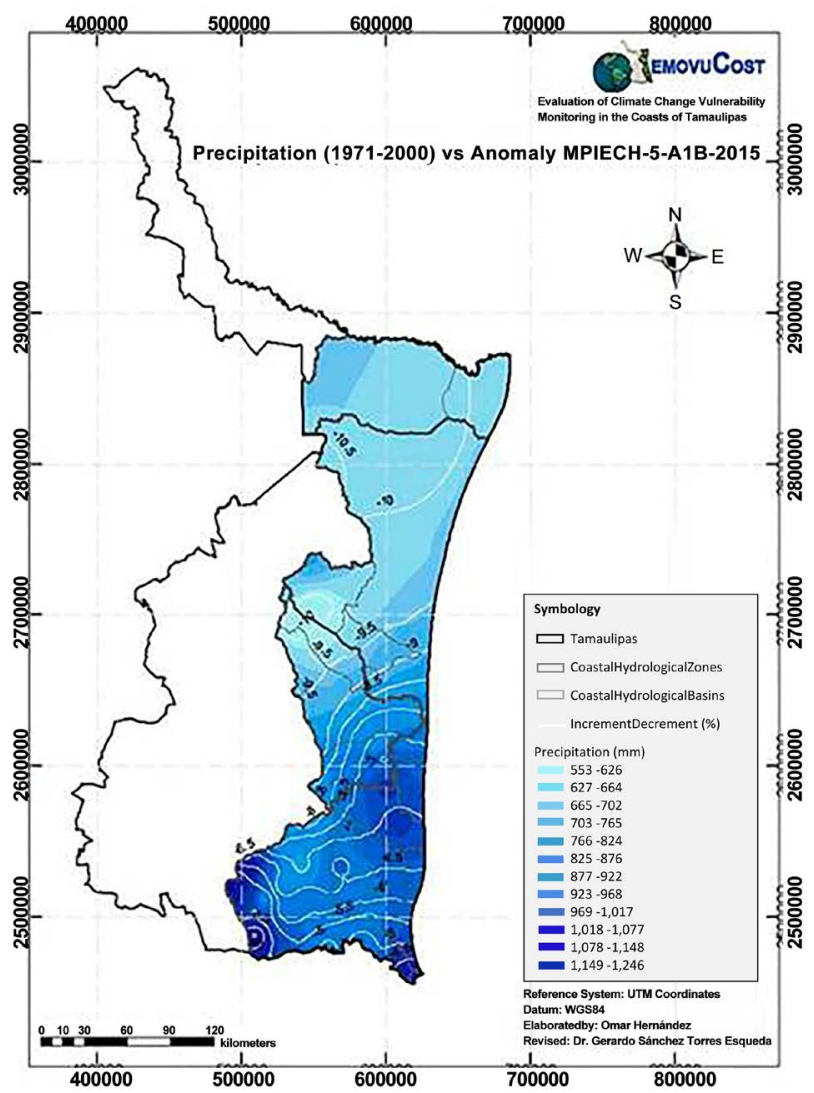

(a)

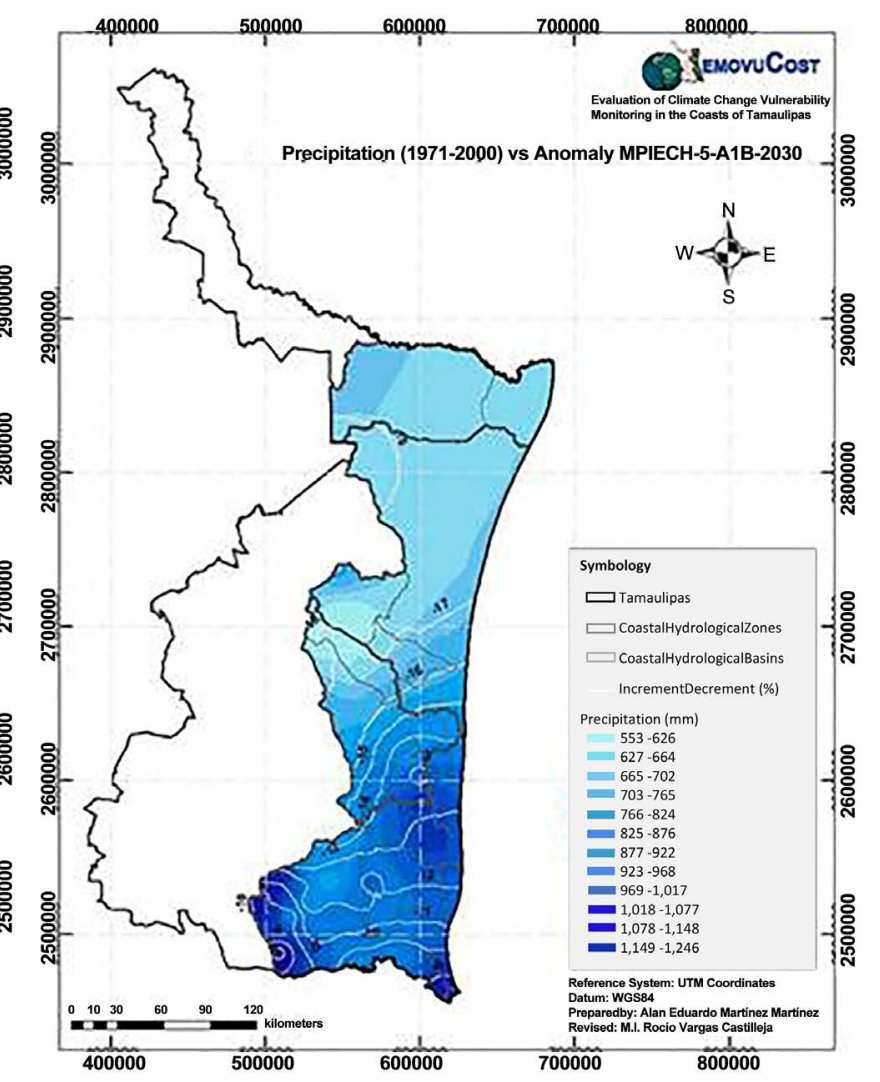

(b)

Figure 1. Precipitation (1971-2000) vs Anomaly A1B MPIECH-5 2015 and 2030. Source: EMOVUCOST "Evaluation and Monitoring of Climate Change Vulnerability in the Coast of Tamaulipas”, 2014.

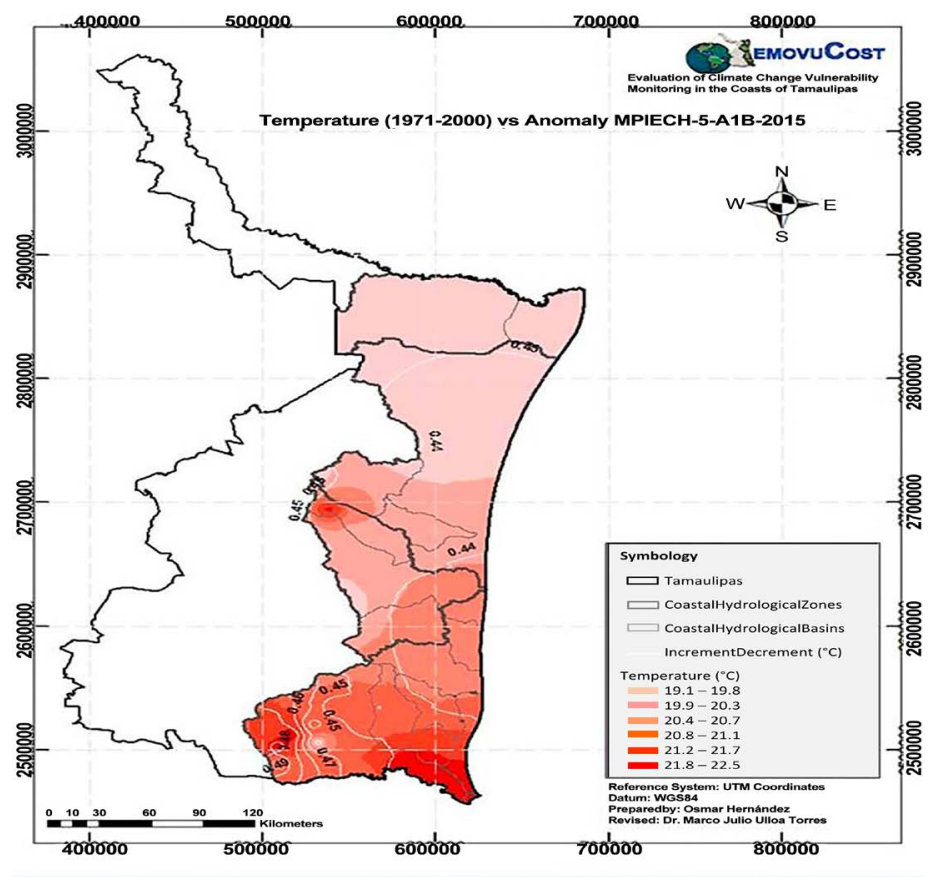

(a)



(b)

Figure 2. Temperature (1971-2000) vs Anomaly A1B MPIECH-5 2015 and 2030. Source: EMOVUCOST "Evaluation and Monitoring of Climate Change Vulnerability in the Coast of Tamaulipas", 2014. 
make it possible to have relevant data according to the tendency in the precipitation changes from the study area. Considering the periods 1961-2010 to analyze if there are any type of projections of climate change that had been estimated for the study area, it is determined how the hygrograms of runoff associated to different return periods will vary and how this will affect the availability of water from the basin. Variations in water availability are determined taking into consideration the impact of climate change every ten years for the period 2010-2030.

\subsection{Social Variables}

The social variables that are relevant to analyze in this research are: historical, current and future population growth until 2030, in relation to water consumption, the Human Development Index (HDI), which implies education, income and health. The demographic growth is part of the economy dimension, population, surface area, income and production. These give a broad trace of current and potential resources. Besides population, surface area, income (measured by the gross national income) and production (measured by the gross domestic income) are used to standardize other indicators. The main indicator of economic development is reflected in the increment of economic productivity and wellbeing material, as population average of a country [6].

Human Development Index (HDI) is another indicator composed by three dimensions: health, education and income, each dimension is measured from variables set by the United Nations. Calculating the HDI at the municipal level requires specific information such as: growth and total municipal population of the study area, scholarship, marginality and urbanization in relation to urban services, more preponderant activities, income per capita, per capita and sectorized water consumption, economically active population (EAP) by sector activity, as well as future scenarios, communities with more water shortages, and data related to precipitation, evapotranspiration and runoffs.

\subsection{Economic Variables}

The economic variables that are relevant to analyze in this research are: the preponderant economic activity by sectorization in the region (Tampico, Madero and Altamira) being a water consumer for the development of its activity reflecting an impact in the production and therefore on growth and development. It is used to obtain this updated statististical data through official sources such as CONAPO, INEGI, INE, IPCC, CONAVI, etc.

\section{Methodology of the Indicator of Water Availability (IDA)}

\subsection{Description}

The indicator is guided to measure the upcoming water availability in the lower basin of Guayalejo-Tamesi River which is the supply source for the conurbation formed by municipalities Tampico, Madero and Altamira, located in the south of the State of Tamaulipas to climate change scenarios and the mobility of the activities from the population development of the basin users in the 2010-2030 period. 


\subsection{Methodology}

One of the fundamental parts to analyze for the development of the (IDA) is the quantitative that comes from the application of mathematical models, which from the incorporation of the computer science, has simplified the inference and have supported the prediction, the development of computational tools, particularly the software of hydrological simulation, has been developed as a group of geospatial-hydrological tools for engineers and hydrologists, and has allowed a quick progress in knowledge and integral management of basins, it is used to process basin data after doing an initial compilation and preparation of the land information; and the qualitative, that represents a major challenge in economic engineering, to convert complex variables as the human development, the growth of the economic activity, and social demographic mobility in water requirement.

\subsection{Relevance}

The approach tries to integrate the economic, social and environmental components with the purpose of providing a vision systemic and joint which is considered essential to understand and regulate the concerning processes to the sustainability of the socioeconomic welfare. Traditionally when dealing with socio-economic indicators, these make reference to the use of the sources, costs or interest, the investments and its rates of return.

In the conception of the economic component here treated it is understood that the main economic activity is the life itself in such a way that when satisfying the survival basic needs such as feeding, the continuity process is guaranteed which has a dynamic and multidimensional character. In a synthetic way, it is said that the economic activity consists on the faculty that the human has to act over nature in order to satisfy his needs, and it is manifested by the order of its effort and work dedicated to reach this aim.

The satisfaction of the basic necessities gives rise to others of aspirational type whose fulfillment gives rise to the socioeconomic development that in the science of the society is included in the concept of development and is usually measured in three basic dimensions proposed by the UN, like the Human Development Index and we find this as a determinant of water consumption in such a way that the population growth and its socioeconomic mobility maximizes the consume. In terms of environmental factors we can start with the modeling of water availability and the modeling of climate change scenarios in what corresponds to temperature and precipitation in the lower basin according to the study are, projected variables in the period 2015-2030.

\subsection{Category}

Its construction comes from a self-effort which is not part of an institutional project of the basin intervention.

\subsection{Reachment}

Local-regional: the lower basin of Guayalejo-Tamesí River corresponding to Tam- 
pico, Madero and Altamira in the south of the state of Tamaulipas.

\subsection{The Development of the Socioeconomic Indicator of Water Availability (IDA)}

Defining (AC): Annual consumption per habitant expressed by the result from the daily consumption per habitant in days per year.

The calculation results from the variable of consumption daily per capita $(\mathrm{Cd})$, it is oriented and based on the National Water Commission [7] in the manual of drinking water and wastewater, which estimates the per capita consumption for hot climates over the average of $22^{\circ} \mathrm{C}$ in 400 liters per day, residential home, 230 liters per day in average home and 185 liters per day in popular home. Average weight is taken in relation to the socio-economic levels, resulting in a per capita consumption of 271.67 liters per day by the number of population represented in the following data established by [4]; giving as a result the weighted daily consumption per capita, this variable is based with represented data from different sources of geographic information on the Human Development Indicator (HDI), which is representative for calculating its theoretical and methodological consistency of the different socioeconomic strata which it is subject the study area.

Defining (Cd)

$$
C d=\frac{\sum\left(E_{1}+E_{2}+E_{3} \cdots\right)}{N_{E}}
$$

where:

$$
\begin{aligned}
& \text { Cd = Daily consumption per inhabitant, Lts/day } \\
& \text { E1= Daily endowment of high social stratum Lts/day } \\
& \text { E2 = Daily endowment of medium social stratum Lts/day } \\
& \text { E3 = Daily endowment of low social stratum Lts/day } \\
& \text { NE = Number of social stratums }
\end{aligned}
$$

Having the consumption daily per capita (Cd) is multiplied by the total population and at the same time by ten times having as a result the annual consume per inhabitant (CA).

Defining (CA)

$$
C A=C d * P T * 365
$$

where:

$$
\begin{aligned}
& \text { CA = Annual consume per inhabitant } \text { Lts } \\
& \text { Cd = Daily per capita consume, Lts } \\
& \text { PT = Total population } \\
& 365 \text { = Days of the year }
\end{aligned}
$$

The variable total population (PT), is determined by the growth factor. It can vary depending on the study area, in the specific case of the population of Tampico, Madero and Altamira.

The calculation is oriented in these three municipalities with a population for 2010 of 706.771 inhabitants, according to published data from the National Institute of Statistics and Geography [8], with a growth rate of $30 \%$ for the period between 2005 and 2010 . 
Altamira presented a major growth of the area, it went from having a population of 153,807 in 2005 to 212,001. This increase represents a growth rate of $31.2 \%$ similar to the overall growth rate of the area, which is closely linked with the entry into operation of the industrial port of Altamira.

If the annual consumption per capita (CA), applies a weighted growth factor (CA) $\mathrm{Cp}$, breaking it down as follows, would read:

Defining (CA) Cp

$$
C p=\frac{\sum(t c T+t c M+t c A)}{N_{m}}
$$

where:

$\mathrm{Cp}=$ Population growth factor, $\%$

tcT $=$ Tampico growth trend, \%

$\mathrm{tcM}=$ Madero growth trend, \%

$\mathrm{tcA}=$ Altamira growth trend, $\%$

$\mathrm{Nm}=$ Municipality number

In this context changes in the population of Tampico and Madero city are due to the municipalities no longer have land reserves which would explain the increase in the population of the municipality of Altamira, which has land reserves.

According to [9] it is estimated that by 2030, Altamira has increased its population to almost $50 \%$, which would generate more demand for water uses in a short, medium and long term, data are shown in the Table 2.

In relation to the variable agricultural consumption $(\mathrm{Ca})$ and industrial consumption $(\mathrm{Ci})$. The calculation is based on the data established by sectorization that for water use establishes in the Report of the Official Journal [10], the Agricultural activity occupies $76 \%$ of concessioned water, supply for public use $14 \%$ and $10 \%$ industrial activity.

On the other hand, reviewing and compared with data provided by the Organismo de Cuenca Golfo Norte of the CONAGUA [11] a report established in the Official Gazette 2011 Diario Oficial de la Federación [10], reaffirm the water demand trend in the agricultural sector, followed by the domestic and industrial. This parameter helps to calculate water consumption per sector, as direct demands of the natural resource that impacts directly in its availability and with that contributes to satisfaction of economic development needs, having per capita consumption in liters per day.

Defining $(\mathrm{Ca})$ and $(\mathrm{Ci})$

$$
\begin{aligned}
& C a=\sum E a s+E a s b t \\
& C i=\sum E a s+E a s b t
\end{aligned}
$$

where:

$$
\begin{aligned}
& \mathrm{Ca}=\text { Agricultural annual consumption, } \mathrm{Mm}^{3} \\
& \mathrm{Ci}=\text { Industrial annual consumption, } \mathrm{Mm}^{3} \\
& \text { Eas = Surface water extraction, } \mathrm{Mm}^{3} \\
& \text { Easbt = Extraction of groundwater, } \mathrm{Mm}^{3}
\end{aligned}
$$

Substantiated this variable with data represented from different sources of geographic information about the economic activity by economic sector, theo- 
retical and methodological consistency to which the study area is subject.

In relation to the variable $(\mathrm{Ca}+\mathrm{Ci}) \mathrm{Ce}$, these are subject to three likely scenarios of economic growth that may occur during the period 2010-2030.

Defining (Ce)

$$
C e=E 1, E 2, E 3
$$

where:

$\mathrm{Ce}=$ Economic growth, \%

$\mathrm{E} 1=$ Scenario of economic growth of $1 \%$

$\mathrm{E} 2=$ Scenario of economic growth of $3 \%$

E3 $=$ Scenario of economic growth of $5 \%$

Therefore we have that:

$$
I D A=(C A) C p+(C a+C i) C e=D T
$$

where:

$\mathrm{CA}=$ Annual per capita consumption expressed by the result of daily consumption per capita in days per year.

$\mathrm{Ci}=$ Water consumption industrial sector $/ \mathrm{Mm}^{3}$

$\mathrm{Cp}=$ Population growth factor $/ \%$

$\mathrm{Ce}=$ Growth factor by economic activity $/ \%$

$\mathrm{DT}=$ Total demand consumed in annual periods by users of the Lower Basin of the River Guayalejo-Tamesí/ $\mathrm{Mm}^{3}$

$\mathrm{Ca}=$ Water consumption in the agricultural sector $/ \mathrm{Mm}^{3}$

Having the total demand for water by the users of the basin, it is important to define the variable (DAC), which is the one that reflects the water availability to scenarios of climate change, for the development of this variable the natural availability is considered (ND) corresponding to the section 57 of the lower basin of Guayalejo-Tamesí River reflected in Table 2, published in the DiarioOficial De La Federación [10]. The reduction factor because of precipitation anomalies (Ap) is obtained by weighing the scenarios modeled and simulated from A1B, projected until 2030 in which is expected to decline $15 \%$ in precipitation.

Assuming:

$\mathrm{Ap}=-15 \%(\mathrm{~A} 1 \mathrm{~B}, 2030)$

Therefore we have:

Defining (DAC)

$$
D A C 2030=D N(1-A p)
$$

where:

$\mathrm{DAC}=$ Availability of water to climate change scenarios, $\mathrm{Mm}^{3} /$ Year

$\mathrm{DN}=$ Natural availability, $\mathrm{Mm}^{3} /$ Year

$2030=$ Factor projection by anomalies in precipitation/period

Ap $=$ Precipitation anomalies $/ \%$

Formula of the Socioeconomic indicator of Water Availability, IDA:

$$
I D A=\frac{D N(1-A p) ? D A C_{2030}}{(C A) C p+(C a+C i) C e=D T}
$$


Table 2. Usage of water by zone in the Lower basin of Guayalejo Tamesí River.

\begin{tabular}{cccc}
\hline & Surface water & Ground water & Total \\
\cline { 2 - 4 } Usage of water & $\left(\mathrm{Mm}^{3} /\right.$ Year $)$ & $\left(\mathrm{Mm}^{3} /\right.$ Year $)$ & $\left(\mathrm{Mm}^{3} /\right.$ Year $)$ \\
\hline Aquaculture & 0.32 & 0.028 & 0.348 \\
Agricultural & 315.31 & 26.879 & 342.189 \\
Domestic & 0.1 & 0.239 & 0.339 \\
Industrial & 107.44 & 0.119 & 107.559 \\
Multiply usage & 0.28 & --- & 0.28 \\
Livestock & 0.25 & 0.394 & 0.644 \\
Urban public & 84.89 & 3.254 & 88.144 \\
Services & 0.37 & 0.132 & 0.502 \\
Total: & 508.96 & 31.045 & 540.005 \\
\hline
\end{tabular}

Sources: Excel data base given by Water Program Agency Northern Gulf Basin from CONAGUA, 2012.

where:

$\mathrm{CA}=$ Annual consumption per capita expressed by the result of daily consumption per capita in days per year.

$\mathrm{DT}=$ Total demand in cubic meters consumed in annual periods by users of the Lower Basin Guayalejo-Tamesí river.

$\mathrm{DN}=$ Natural availability, $\mathrm{Mm}^{3} /$ Year

$\mathrm{Ca}=$ Water consumption in the agricultural sector, $\mathrm{Mm}^{3} /$ Year

$\mathrm{Ci}=$ Water consumption industrial sector, $\mathrm{Mm}^{3} /$ Year

$\mathrm{DAC}=$ Availability of water to climate change scenarios, $\mathrm{Mm}^{3} /$ Year

$\mathrm{Cp}=$ Population growth factor, $/ \%$

$\mathrm{Ce}=$ Growth factor by economic activity, $/ \%$

Ap $=$ Precipitation anomaly, $/ \%$

It is assumed that surface runoff is reduced in the same proportion as the anomaly of precipitation.

More studies will be required to determine a more accurate rainfall-runoff relation to the impact of climate change. The international evidence is enough to consider that in a higher temperature it will manifest changes in plant cover and changes in natural soil moisture impacting runoff negatively.

\section{Results and Analysis of the IDA Application}

Table 3 reflects the calculation of the Socioeconomic Water Availability Indicator (IDA)

Hydric Stress of the lower basin of Guayalejo-Tamesí River.

The calculation of the Socioeconomic Water Availability Indicator (IDA), if its parameter indicates more than 1.5 , it would reflect water supply capacity of water availability for the development of economic and human activities; if its parameter indicates less than 1.5 getting closer to 1 , it reflects a short-term problem of water supply and if there is a close-up to an indicator of $(<1)$, it represents a hydric stress. As it is presented in the following Table 4. 


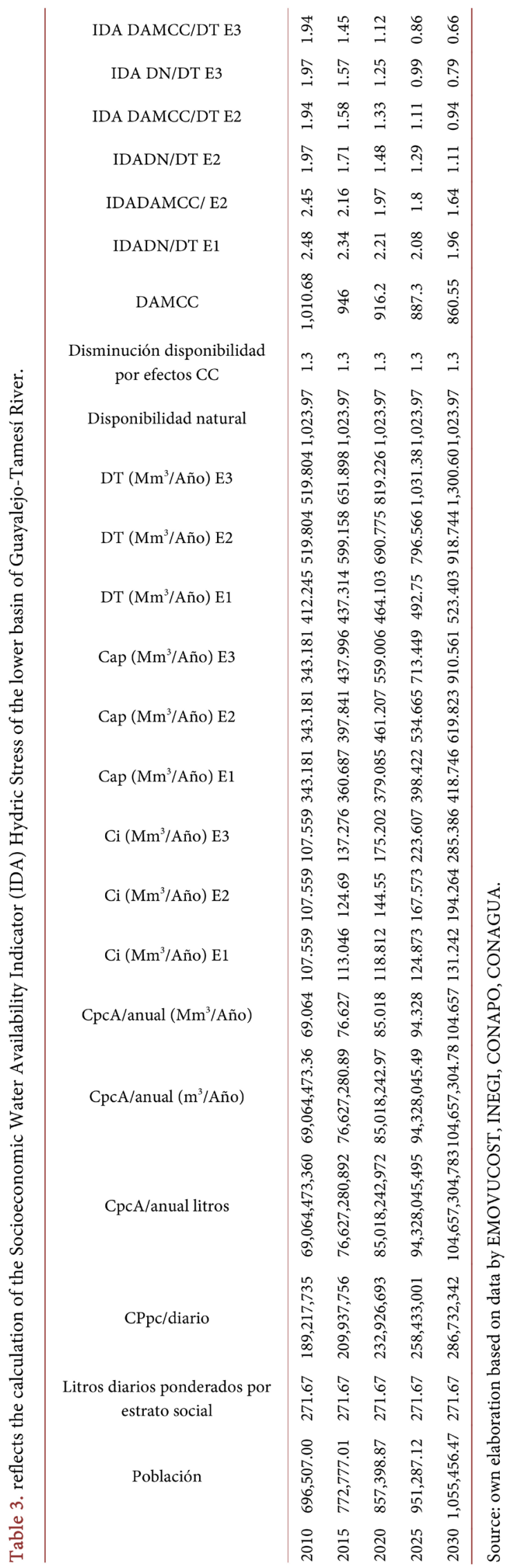


Having as a reference the total demand for the eight variables represented in the formula associated to the trend of population growth and its relationship to the improve of life quality, joined to a precarious economic growth scenario, assuming 5\% exposed as a positive outlook, due to in recent years it hasn't grown more than $1 \%$ and $3 \%$, which impacts in the most representative economic activities in the lower basin of Guayalejo Tamesí river.

Where agriculture, according to data from [12], in the lower part of the basin, from Magiscatzin station to the lagoon system of the Tamesí River, where the metropolitan area is located has an annual consumption of 255 million m3, which $40 \%$ is for irrigation, $28 \%$ for urban public use and $32 \%$ for industry. On the other hand, the consideration of a variability in temperature and precipitation in resource availability with a trend until 2030 with the final results from the project EMOVUCOST [13] "Evaluación y Monitoreo de la Vulnerabilidad al Cambio Climáticoen las Costas de Tamaulipas" where a reduction in the precipitation of the study area can be observed, and therefore, a more critical aridity that could prolonged and increased in future years. Even the most optimistic scenerios show a reduction in the precipitations and an increase in the temperatures which can be observed in the maps 1, 2, 3 and 4 previously showed; showing the performance indicator downward until 2030.

In the first scenario, where it is considered an economic growth of $1 \%$ of GDP, having in mind the static availability of the lower basin of Guayalejo-Tamesí River, it would reflect a favorable indicator of water availability from 1.86 to 1.56 in the corresponding period from 2015 to 2030, limit that corresponds to the research work. With this trend, would be expected a stage of hydric stress to the years after 2030, close to 2050 .

On the other hand, in this same scenario with an economic growth of $1 \%$ of GDP, taking into consideration the availability in scenarios of climate change in the lower basin of Guayalejo Tamesí River, in relation to the precipitation anomaly where it is estimated that there will be a temperature increment of $2.0^{\circ} \mathrm{C}$ and a decrease in precipitation with a trend ranging between $0.055 \%$ and $0.085 \%$ per year, a percentage that is calculated based on the results of the modeling of the "Assessment and Monitoring Vulnerability to Climate Change in the Coasts of Tamaulipas", 2014; giving as a result an indicator from 1.76 to 1.43 in the corresponding period from 2015 to 2030. With this trend a scenario of hydric stress is expected to the years after 2030, close to 2050.

In the second scenario, where an economic growth of $3 \%$ of GDP is considered, taking into account the static availability of the lower basin of Guayalejo Tamesí River, it would reflect an indicator of water availability from 1.71 to 1.11 in the

Table 4. Socioeconomic Water availability indicator parameter (IDA).

\begin{tabular}{cc}
\hline More than 1.5 & Wateravailability \\
\hline 1.5 approaching 1 & Short-termwatersupply \\
$<1$ & Hydric stress \\
\hline
\end{tabular}

Source: Selfelaboration. 
corresponding period from 2015 to 2030 limit that corresponds to the research work. With this trend a water stress scenario would be expected to not more than five years after 2030 .

Having as a starting point the same scenario with an economic growth of $3 \%$ of GDP, considering the availability to climate change scenarios in the lower basin of Guayalejo Tamesí River, in relation to the precipitation anomaly $(\mathrm{Pa})$, where it is estimated that there will be a temperature increase of $2.0^{\circ} \mathrm{C}$ and a decrease in precipitation with a trend ranging between $0.055 \%$ and $0.085 \%$ per year, a percentage that is calculated based on the results of the modeling "Assessment and Monitoring Vulnerability Climate change in the Coasts of Tamaulipas, 2014; gives as a result an initial indicator from 1.19 to 1.02 of water availability in 2025 in the period limit corresponding to the research work. With this trend, a scenario of hydric stress would be expected from 2030.

In the third scenario, where an economic growth of 5\% of GDP is considered, taking into account the static availability of the lower basin of the Guayalejo Tamesí River, it would reflect an indicator of water availability from 1.57 to 1.25 in the corresponding period from 2015 to 2020 . With this trend, a scenario of hydric stress would be expected from 2025 and an indicator from 0.99 to 0.79 , at the limit of the study period.

Having as a starting point in the same scenario with an economic growth of $5 \%$ of GDP, considering the availability to climate change scenarios in the lower basin of Guayalejo Tamesí River, in relation to the precipitation anomaly (Ap), where it is estimated that there will be a temperature increment of $2.0^{\circ} \mathrm{C}$ and a decrease in precipitation with a trend ranging between $0.055 \%$ and $0.085 \%$ per year, percentage that is calculated based on the results of the modeling of the "Assessment and Monitoring Vulnerability Climate change in the Coasts of Tamaulipas, 2014"; giving as a result an initial indicator from 1.48 to 1.17 of water availability until 2022 and from 0.92 to 0.72 in the period limit corresponding to the research work. With this trend a scenario of hydric stress would be expected from 2023

\section{Conclusions}

Given the lack of research on binding indicators of water availability, the work described here fulfills the objective of the application of the IDA as an approximation to the construction of an indicator of water availability in scenarios of climate change, involving economic, social and environmental variables in order to identify water stress in a region, being a new experience at the national and regional level, which must be approached in a generalized way by the entities linked to the development of these territorial spaces, which will allow a better social and economic use of the hydrological system for the management of a sustainable integral plan.

The application of this indicator of water availability (IDA) may be convey to other regions, as long as they have hydrological modeling studies and climate change scenarios in relation to temperature and precipitation, as well as socioe- 
conomic data on water demand by economic sector.

When applying the indicator of Water Availability (IDA), in the metropolitan area of southern Tamaulipas (Tampico, Madero and Altamira), three possible scenarios are estimated in relation to economic growth of $1 \%, 3 \%$ and $5 \%$ as an expression of gross domestic product (GDP) in projection until 2030.

Taking into account the proposed scale of water availability, where it is established as a result of dividing the water availability of the basin with precipitation anomaly impact between the water demand to satisfy the requirements of the socioeconomic activities of the population, the product is an integer number of a digit and fractions. When the result is 1.5 , it means that the availability of water is sufficient; if the result tends to 1 , it means water supply in the short-term; and if it is $<1$ means imminent hydric stress.

The application of the formula allows to manifest that the indicator of the water supply critical scenery by 2030, considering a 1\% GDP growth along with the anomaly by precipitation, it would have an indicator of 1.76 to 1.43 in the period corresponding from 2015 to 2030 . With this trend a scenario of water availability is expected until 2030 .

In a second scenario with a $3 \%$ GDP growth along with the anomaly by precipitation, it would have an indicator of 1.62 to 1.02 , in the period corresponding from 2015 to 2030 . With this trend a water stress scenery is expected from 2030.

In a third scenery with a 5\% GDP economic growth along with the anomaly by precipitation, it would have an indicator of 1.48 to 0.72 , in the period corresponding from 2015 to 2030. Projecting a problem of water stress from 2025.

It is assumed that there are externalities that have not been studied and that impact the water availability, which they are expressed as constraints of the indicator, such as temperature, culture, upstream natural resources management, and surface runoff; so this is reduced in the same proportion as the anomaly by precipitation.

It will take more research to determine a more accurate rain-relationship runoff to the impact of climate change. The international evidence is sufficient in order to considering that at higher temperature, changes in plant cover and natural soil moisture will manifest, so it will negatively impact the runoff [14].

To satisfy the actual needs of water and the ones the country development demands in the future, it is required an enormous investment, so it will be needed to mobilize all sources of public and private financial resources, a policy of sustainability water issues, it is necessary to seek coordination between the three levels of government and consultation with the various sectors of users and citizens.

\section{References}

[1] Quiroga, R. (2007) Guíametodológica para desarrollarindicadoresambientales y de desarrollosostenibleenpaíses de América Latina y el Caribe Recuperado de: http://www.iadb.org/intal/intalcdi/PE/2011/08717.pdf

[2] INECC (2012) GuíaMetodológica para la Evaluación de la Vulnerabilidad ante CambioClimático, Estudiorealizadoen el marco del Proyecto de la Quinta Comunicación Nacional ante la Convención Marco de las NacionesUnidas para el Cam- 
bioClimático (UNFCCC), coordinadopor el Instituto Nacional de Ecología y CambioClimático (INECC) con recursos del Global Environment Facility (GEF), a través del Programa de las NacionesUnidas para el Desarrollo (PNUD). México, 2012. http://www.inecc.gob.mx/descargas/cclimatico/2012_estudio_cc_vyagef3.pdf

[3] INEGI (2005) Censo General de Población y Vivienda, TabuladosBásicos. Tamaulipas, México1995, 2000, 2005, 2010 y 2011.

[4] INEGI (2010) Censo General de Población y Vivienda, TabuladosBásicos. Tamaulipas, México1995, 2000, 2005, 2010 y 2011.

[5] CONAPO (2010) Dinámicademográfica 1990-2010 y proyecciones de población 2010-2030.

http://www.conapo.gob.mx/work/models/CONAPO/Proyecciones/Cuadernos/28_ Cuadernillo_Tamaulipas.pdf

[6] WORLD BANK, Report (2002) Recuperado de: www.worldbank.org/data/wdi2002/tables/table1-1.pdf

[7] CONAGUA (2007) Manual de Agua Potable, Alcantarillado y Saneamiento. Edición 2007ISBN: 978-968-817-880-5, Editor: Secretaría de Medio Ambiente y RecursosNaturales.

http://www.conagua.gob.mx/conagua07/publicaciones/publicaciones/Libros/03Carc amosDeBombeoParaAlcantarilladoFuncionaleHidraulico.pdf

[8] INEGI (2011) Censo General de Población y Vivienda, TabuladosBásicos. Tamaulipas, México1995, 2000, 2005, 2010 y 2011.

[9] CONAPO (2012) Dinámicademográfica 1990-2010 y proyecciones de población 2010-2030.

http://www.conapo.gob.mx/work/models/CONAPO/Proyecciones/Cuadernos/28_ Cuadernillo_Tamaulipas.pdf

[10] DOF (2011) del 18 de Julio de 2011. http://dof.gob.mx/nota_detalle.php?codigo $=5201212 \&$ fecha $=18 / 07 / 2011$

[11] CONAGUA (2012) ProgramaHídrico Regional, Visión 2030, RegiónHidrológicoAdministrativa IX Golfo Norte. Marzo 2012.

http://www.conagua.gob.mx/conagua07/publicaciones/publicaciones/9-sgp-17-12g n.pdf

[12] SEDUMA (2011).

http://seduma.tamaulipas.gob.mx/wp-content/uploads/2011/12/Boletin-Digital-4_w eb.pdf

[13] EMOVUCOST (2014) Evaluación y Monitoreo de la Vulnerabilidad al CambioClimáticoen las Costas de Tamaulipas., en. http://cambioclimatico-tamaulipas.org/home/principal.php?page=home

[14] IPCC (2008) El CambioClimático y El Agua GrupoIntergubernamental de Expertossobre el CambioClimático OMM PNUMA Documentotécnico VI del IPCC. http://www.ipcc.ch/pdf/technical-papers/ccw/climate-change-water-sp.pdf 
Submit or recommend next manuscript to SCIRP and we will provide best service for you:

Accepting pre-submission inquiries through Email, Facebook, LinkedIn, Twitter, etc. A wide selection of journals (inclusive of 9 subjects, more than 200 journals)

Providing 24-hour high-quality service

User-friendly online submission system

Fair and swift peer-review system

Efficient typesetting and proofreading procedure

Display of the result of downloads and visits, as well as the number of cited articles Maximum dissemination of your research work

Submit your manuscript at: http://papersubmission.scirp.org/

Or contact gep@scirp.org 